This is the version of the article/chapter accepted for publication in Sikh Formations: Religion, Culture, Theory published by Taylor \& Francis, https://doi.org/10.1080/17448727.2019.1593305 Accepted version downloaded from SOAS Research Online: http://eprints.soas.ac.uk/30500/

\title{
The control of sacred spaces: Sikh shrines in Pakistan from the Partition to the Kartarpur corridor
}

\author{
Gurharpal Singh \\ gs41@soas.ac.uk \\ School of Oriental and African Studies \\ University of London
}

Key words: Kartarpur, Pakistan, India, Sikhs, Partition, Gurdwaras

\begin{abstract}
In November 2018, to mark the $550^{\text {th }}$ anniversary year of Guru Nanak's birth, the governments of India and Pakistan agreed to develop the Kartarpur corridor over the river Ravi linking Sikhs' two holiest shrines. The initiative is an important symbolic moment in the access to Sikh sacred spaces in Pakistan. This paper examines critically the efforts to control and manage this access since 1947. It assesses the regimes of regulation established by the two states to control access and reflects on the prospects for the Kartarpur corridor to become a 'bridge of peace'. The Sikh case, the paper argues, offers an unusual comparative case-study of closure of sacred spaces to a community in its 'homeland' and 'holy land'.
\end{abstract}




\section{The Control of Sacred Spaces: Sikh shrines in Pakistan from the Partition to the Kartarpur corridor}

In November 2018, the governments of India and Pakistan agreed to open a corridor over the river Ravi linking two important Sikh shrines: Dera Baba Nanak (in India) with gurdwara Darbar Kartarpur Sahib (in Pakistan). A mere 6.3 kilometres and the river Ravi separate these structures that are closely associated with the life and times of Gurn Nanak, the founder of the tradition. But despite this distance the international border that was created in 1947 between the new state of Pakistan and India, and the history of rivalry between the two nuclear-armed neighbours, has limited any serious initiatives to make more accessible sacred spaces in East and West Punjab. The political division of the Indian subcontinent in 1947 was, also in some measure, a spiritual division as the new states established complex systems of regulation to control the access of pilgrims from the two countries. Nowhere was this divide more keenly felt than in the Punjab in which the multi-religious and multi-ethnic tradition of the province was torn asunder by the creation of an arbitrary boundary drawn ostensibly along 'religious' lines. As the religious nationalisms of the Indian National Congress (hereafter the Congress), the Muslim League and the Shiromani Akali Dal (SAD) clashed, some of the key sacred spaces which fell on the 'wrong' side of the boundary line, became the sites of alternative narratives that contested the logic of partition.

In contrast to the study of the politics and history of the partition of India, which has witnessed major methodological and conceptual advances since the 1980s (Talbot and Singh 2008, ch.1), its religious consequences have been largely overlooked. This paper critically explores this neglected dimension by locating the debate in the comparative literature on the 
control of sacred spaces. It then assesses the Sikh case-study through three temporal moments. First, the status of Nankana Sahib, the birth place of Guru Nanak, in the final phase of the transfer of power and how, in the months leading up to $15^{\text {th }}$ August, 1947, Nankana Sahib became the source of a bitter dispute between the British government and colonial state and the Sikh leadership. Second, it evaluates how after 1947 both the governments of India and Pakistan have sought to regulate access by Sikh pilgrims to Nankana Sahib and other scared sites. Third, the paper reviews the prospects for a more open access to these sites for Sikhs in Pakistan suggested by the opening of the Kartarpur corridor. In conclusion, it reflects on the importance of the Sikh case-study for its wider implications for debates about the control of sacred spaces and contested political and religious sovereignties.

The literature on the control of sacred spaces ${ }^{i}$ falls into two broad categories (Hassner 2003). Most common are contestations as a result of schisms, syncretism, and conquest and real estate disputes. Such examples include the conflict between Jews and Muslims over the Temple on the Mount and the Al-Asqa mosque, and in India, the bitter rivalry since the early 1980s between Hindus and Muslims over the control of the Bari Masjid mosque. These disputes raise the issue of 'indivisibility', of zero-sum contestations over rival claims to exclusive ownership of scared spaces (Ibid., 8). But not unrelated, and equally significant, is the more generic political control closely associated with the nature of church-state relations framed by secularism, nationalism and development which define the ideological limits of the religious (Casanova 1994). In the case of the Sikhs, whose sacred spaces were divided in their homeland, the former category is largely irrelevant, but the latter is much more noteworthy in defining their relationship with the state in India and Pakistan, and as the 
mainspring of the Congress's and Muslim League's nationalisms that prescribes the relationship with religious minorities. Accordingly, the term 'control' in this paper is used in two senses: as form of physical control of borders, security and institutions; and as an ideological resource to regulate, discipline and naturalise post-1947 nation- and stateformation. The state in Pakistan is generally viewed as exercising physical control over Sikh sacred spaces whereas the state in India is commonly associated with a more laissez faire approach of a liberal democracy. However, the central argument of this paper is that such a distinction is one of degree not kind: both states seek to exercise control over Sikh sacred shrines as means of managing the Sikh community because its conception of religious and political sovereignty disrupts the narratives of nation formation that led to 1947 and after.

\section{Nankana Sahib and the Partition of Punjab}

On 20 February, 1947, Prime Minister Attlee in the House of Commons announced that the British would leave India by June 1948, and that Louis Mountbatten would succeed Wavell as viceroy. This announcement was made against the rising tide of mass communal violence in India and the decision of the Muslim League to withdraw from the protracted constitutionmaking process stared by the Cabinet Mission Plan in May 1946 (Moore, 1983, 221). At this stage the Labour government's intention was still to transfer power to a united India that would accommodate the competing claims of the Congress and the Muslim League. But following Mountbatten's arrival in New Delhi in late March, he soon concluded the British were 'sitting on the edge of a volcano' that could erupt any time (Mountbatten 1947). At the epicentre of this tension was the Punjab. Here the Muslim League's campaign to oust the inter-communal coalition Unionist government finally materialised on the $2^{\text {rd }}$ March, and was followed by communal rioting in Rawalpindi, Multan, Lahore, Amritsar, Jullunder and Attock. As central Punjab became the 'battle ground for Pakistan' (Mansergh and Moon 
$1980,926)$, the resort to direct action led to mass violence 'organised with extreme savagery', with the massacre of Sikhs and Hindus in Rawalpindi resulting in 5,000 casualties and 35,000 refugees (Ibid., 962). This violence impelled the Sikh political leadership and the Congress to call for the partition of Punjab. But it was a partition on their terms to be defined by cultural, religious and economic factors - not just the head count. If the Muslim League's pursuit of Pakistan laid claim to the whole of the Punjab, then the Sikhs and the Congress would call for a resizing of the province which in turn would turn Pakistan into an empty husk (Mansergh and Moon 1981, 456). In the protracted negotiations between Mountbatten, the Congress, the Muslim League and the Sikh leadership from the end of March and the beginning of June in 1947, the only plan for the transfer of power that the Congress and the Muslim League would agree to was a quick demission of power to the two dominions of India and Pakistan. The division of the Punjab and Bengal was the inevitable outcome of this decision. The $3^{\text {rd }}$ of June Plan envisaged the transfer of power to the new states on 14 and the 15 August, and included a Boundary Commission to demarcate the borders of Pakistan (Moore, ch.4).

The agreement, which was aimed at arriving at a settlement between the Congress and the Muslim League, inevitably marginalised Sikh claims that cut across the principle of Muslim and non-Muslim 'contiguous majority areas'. These claims were on based on religious, cultural, historical and economic factors in order to ensure the community's integrity in face of the majority principle that threatened to divide it equally between India and Pakistan. As Baldev Singh, the defence minister in the Interim Government (1946-47), and the chief Sikh representative on the Viceroy's Executive, was to lament: 'Everything we have in this world is within the border of the Punjab. It is our homeland' (Mansergh and Moon, 1981, 655). All strands of Sikh leadership - SAD, the Congress, the Princes, and 
Baldev Singh himself - forthrightly conveyed to Mountbatten and his staff the imperative of keeping Nankana Sahib, which was in a Muslim majority district, within the territory to be allocated to India. At worst, Nankana Sahib's special place in Sikhism merited the designation of a 'free city', controlled by no one, and open to all (Mansergh and Moon 1980, 183-4). Indeed, the principles which underpinned the Sikh claims for Nankana Sahib, and other territories to be excluded from Pakistan, according to Baldev Singh, rested on the assurances given to the Sikhs by the British about the protection of the community. These included the need to disturb as little as possible its homogeneity and integrity, that the division was forced on Sikhs (and Hindus) by the Muslim League, and to avoid future conflict by excluding Muslim areas in areas of high Sikh populations (Mansergh and Moon, 1981 476-69). It was, in essence, the application of the claim for Pakistan in reverse. Mountbatten noted, with some irony, that the Sikhs 'want - on religious grounds like Muslims - to take over and dominate in areas in which they are a minority' (Ibid., 470)

The British government, in the words of the Secretary of State for India, sought 'to keep the Sikhs quiet until the transfer of power' (Mansergh and Moon 1981, 712) by the device of a Boundary Commission that was tasked with delineating the border between India and Pakistan. In undertaking its work the commission was required to take into account factors other than the simple majority/minority Muslim and non-Muslim areas. Both the Secretary of State for India and Mountbatten believed that the commission would provide a resolution to Sikhs claims. The Sikh leaders, in contrast, reluctantly acquiesced to the $3^{\text {rd }}$ June Plan, which made no mention of the Sikh claims, and the terms of reference of the Boundary Commission, ${ }^{\text {ii }}$ but they also made no secret of their intention to redraw the boundary if the outcome seriously impaired their interests (The Times of India, 5 June, 1947). 
In the debate in the House of Commons on the India Independence Act on 14 July, 1947, the Under Secretary of State for India, Arthur Henderson, sought to clarify the inclusion of 'other factors' in the terms of reference of the Boundary Commission. This addition he insisted had been made

by the Prime Minister to enable the Commission to have regard to the special circumstances of the Sikh community in the Punjab where considerations such as location of their religious shrines can be reasonably taken into account up to a point (Hansard, 14 July, 1947).

However, he was at pains to stress that it was 'for the Commission itself to decide what are the other factors and how much importance should be attached to all or any of them' (Ibid., emphasis added). But shortly after this statement, Henderson faced a written Parliamentary question on whether the consideration of 'other factors', including religion, applied only to Sikhs; and as such, whether minor local variations or substantial inroads into majority areas were contemplated. The response of the Secretary of State for India, Henderson's superior, was to quickly backtrack from this concession: religious shrines of other communities, he asserted, would receive equal treatment if the Boundary Commission so decided (Mansregh and Moon 1983, 329).

The Sikh leadership's response to these manoeuvres was to organise, mobilise, lobby and argue the community's case before the Punjab Boundary Commission. After the riots in March, militias were established and arms collected for direct action in the event of the boundary award being unfavourable to the community's claims. Some have suggested that this amounted to a substantive conspiracy that envisaged the extensive sabotage of Sikh settlements in West Punjab, the assassination of Jinnah, and the involvement of Sikh princely states in the creation of Khalistan comprising the Lahore division (Mansergh and Moon 1983, 537-8).The precise nature of this conspiracy remains highly contested, but in the weeks 
before the award the armed militias were very much in action in ethnically cleansing East Punjab of its Muslim population (Brass 2003).

Against the rising tide of communal violence, protests and conferences were organised to air the community's grievances. During the province-wide protest on 8 July to mark 'Nankana Sahib Day', the Reuter's Indian service reported that India's 5.7 million Sikhs 'wore arm bands at the British plans to split their community'. Gurdwara congregations throughout Punjab approved a resolution declaring that 'any partition that did not secure the integrity and solidarity of the Sikh community would be unacceptable and create a difficult situation'. Sikh leaders openly proclaimed that there would be no peace in the Punjab 'if the Sikhs were dissatisfied with the partition' (Mansergh and Moon 1983, 17-8). Baldev Singh, at a gathering in Delhi gurdwara, exhorted his congregation to 'make all sacrifices if the verdict of the Boundary Commission goes against them' (Ibid., 18) A day after this protest, Giani Kartar Singh, the head of SAD, in a meeting with Governor of Punjab, issued what the latter described as the nearest thing to a Sikh ultimatum:

that they [the Sikhs] must have one canal system; they must have Nankana Sahib; finally, the arrangements must be such as to bring three-quarters or at least third of the Sikh population into East Punjab... The Giani asserted that unless it was recognised by HMG, the viceroy and the party leaders that the fate of the Sikhs was a vital issue in proceedings of the transfer of power, there would be trouble (ibid., 72-3).

To coincide with the sittings of the Punjab Boundary Commission, the Sikh leadership also decided to hold a major conference at Nankana Sahib on 27 July to demand its inclusion in East Punjab. Fearing widespread disorder, Sir Evan Jenkins, the Governor of Punjab, declared the gathering illegal, imposing a strict clamp down on the travel to and from the gurdwara from all areas of the province. A security cordon was established around the city of Nankana Sahib and the surrounding districts by the police and armed troops. Aircrafts 
dropped leaflets on Sikh areas discouraging them from sending jathas (armed bands) towards Nankana Sahib. In spite of these measure, and open firing on the crowds by the troops, several thousand Sikhs were able to gather for the conference and pass anti-Pakistan resolutions (Ibid., 309-10). The gathering dispersed the following day, but not before the troops had caused confusion and mayhem. The incident was raised at the Viceroy's Staff Meeting the same day, with Mountbatten questioning the Governor's wisdom in imposing a ban. Recognising that the issue of Nankana Sahib would continue to evoke a strong feeling among Sikhs, one constitutional advisor at the meeting suggested the city be given a Vaticanlike status. Again however decisive executive support for the proposal was not forthcoming: it was decided only to raise the issue with the Chairman of the Boundary Commission who could forward this suggestion to the Muslim League, and there appears to be no evidence that the matter was followed through (Ibid., 337).

A day before the Nankana Sahib conference, Giani Kartar Singh sent to the private secretary of Mountbatten a small pamphlet outlining the case for the inclusion of the Nankana Sahib tract in India. He drew attention to the importance of Nankana Sahib as one of Sikhs' most important spiritual centres. 'This place', he concluded, is 'the holiest of the holy and comparable in sanctity only to the Mecca of the Muslims in the Arabian peninsula.' It had a flourishing community and an estate of 17,000 acres to support it provided by Maharaja Ranjit Singh. To leave it in Pakistan 'would be like insulting the heart against the body' (Singh 1991, 294).

In the memorandum presented to the Punjab Boundary Commission, Justice Harnam Singh outlined in detail the religious, economic and geographic 'other factors' for consideration of the Sikh community's case. The principal gurdwaras associated with the life 
and time of the Gurus, he insisted - Janam Asthan Nankana Sahib, Dera Sahib, Darbar Sahib

Kartarpur, and Gurdwaras Chomala and Chhevin Padsha - were in West Punjab. Lahore itself was popularly referred to as 'the Guru's cradle' (Ibid., 252). But these were no ordinary shrines of saints and religious leaders as the Muslim League's submission alleged. Rather, as Justice Teja Singh subsequently made clear in his report to the Boundary Commission

The gurdwaras, the situation of which is sought to be used as factor in the demarcation of the boundaries, are those places of worship which were either founded by the ten Gurus or were established long ago to commemorate particular incidents that happened during their lives and with which they are connected...Now, to the Sikhs the ten Gurus are what Christ is to Christians, Hazrat Mohammad is to Muslims and the principal gods who are believed to be the incarnation of Vishnu are to Hindus...It is a mistake to put them on the same footing as the religious places founded by or associated with saints or other religious men howeverso prominent or respected they might be. There are hundreds of gurdwaras that were established by Sikh saints or which were built in the memory of Sikh martyrs but none of them enjoys the sacred character that [is] reserved for the class mentioned above, and the only shrines of the Muslims that in respect of sacredness and importance can compare with the gurdwaras of that class are the shrines that stand in Mecca and Medina (Ibid., 358).

The Sikhs, Teja Singh argued, were not laying claim to territories associated with all these gurdwaras, but principle ones like Nankana Sahib which defined their 'homeland' and 'holy land'. As he summarised:

Therefore I submit that when you are considering this question [of boundaries] the special features of the Sikh community should be taken into account...for the Sikhs, the city of Amritsar, the city of Nankana Sahib in [the] Sheikhupura district, the city of Kartarpur in Shahargarh tehsil [the] Gurdaspur district, are the Mecca and Medina and their Hardwar and Benares (Ahmed 133).

Finally, in the run-up to boundary award, there was flurry of activity to lobby Mountbatten, HMG in London, and the Punjab administration. On the 7 August, the Maharaja of Patiala wrote to Mountbatten that on Nankana Sahib 'Sikh sentiment about this is so strong it would be dangerous to minimise it, as under no circumstances can they [the Sikhs] be persuaded to allow this to go into foreign territory' (Mansergh and Moon 1983, 564). In early August, Principal Ganga Singh and Meherban Singh Dhupia were sent to 
London to meet the Secretary of State of India before the Boundary Commission announced the award. Attlee refused to see them. The Secretary of State for India rebuffed them by noting that the 'matter was out of his hands', and he was only prepared to meet 'such distinguished representatives of the great Sikh community ... [to] make their acquaintance' (Ibid., 621). Major Short, who was the main interlocutor between the Viceroy's staff and the Sikh leadership, was impressed upon to convey Sikh concerns. Responding to apprehension within Mountbatten's staff that Sikhs were likely to cause trouble if the award went again them, Short counselled that if Nankana Sahib were accorded the status of 'Vatican municipality of some sort and free entry and visit', Sikh resentment could be assuaged because 'their hearts [would] thus be touched, [and] their heads will be cooled' (Singh 1991, 468). Earlier, Giani Kartar Singh in meeting with the Punjab Governor had all but repudiated the understanding that the Sikhs would accept the Boundary Commission's report. Querying the authority of Baldev Singh to accept the outcome without wider consultations within the community, he warned that the Sikhs would not take the outcome 'lying down' and retained the right by using direct action to revise any unfavourable outcome. At the end of his meeting, according to Jenkins, Giani Kartar Singh 'burst into tears' and implored him to help the community (Mansergh and Moon 1983, 429-31.) Jenkins, who was viewed by the Muslim League as pro-Sikh, and had regularly been warning New Delhi of the impending war of communal succession, reassured Giani Kartar Singh that he saw no reason why Sikh access to Nankana Sahib would not continue after August 14/15, but added as an aside that the Sikhs would 'have to accept the award and have to come into line if the two dominions [of India and Pakistan] were to enforce it' (Ibid., 430). Jenkins however could not conceal his disdain for the Sikh leadership who he believed had 'made a great mess of the whole Sikh question'. 'The real solution', according to him, 'was to get rid of the non-Punjabi-speaking districts 
and to keep the rest of the Punjab in Pakistan. I think the Sikhs appreciate this now; but it is too late to do anything about it' (Ibid., 430).

In the event, the 'other factors' on which the Sikh case so vitally depended, played a minimal role in delimitation of the new international boundary in the Punjab. The Punjab Boundary Commission failed to provide an agreed report, leaving Sir Cyril Radcliffe to make the final determination which, with minor adjustments of territory, followed closely the principle of Muslim and non-Muslim 'contiguous majority areas'. The award was scheduled to be made before the independence of Pakistan (14 August) and India (15 August), but was deliberately delayed lest its consequences reflected poorly on the Raj (Ibid., 760). And despite the official commitment which Mountbatten was able to extract from Jinnah, Nehru, Patel and Baldev Singh regarding the rights and safety of religious minorities in India and Pakistan, the reality after the 15 August was mass violence in which millions of people in Punjab became refugees. The intensity of this violence was most acute in East Punjab because the Sikh leadership organised the systematic ethnic cleansing of Muslims to compensate territories forgone on West Punjab (Singh 2013). For Sikhs, an international boundary across their 'homeland' and 'holy land' would create a deep sense of spiritual loss, a longing that was eventually inscribed into the daily ardas (supplications), which pleads for these shrines to be eventually united with the panth (the Sikh community) in free and unhindered access (Singh and Fair 2000, 256). But after 1947, without the impartial role of the colonial state, access to sacred spaces such as Nankana Sahib would be determined by official policies of India and Pakistan. 


\section{Access to Sikh sacred spaces in Pakistan post-1947}

Recent research has demonstrated that for individuals the partition was a long, drawn-out process which continued to have implications for refuges for several decades afterwards (Zamindar 2007). For collective groups, on the other hand, the states of India and Pakistan quickly establish new regulatory regimes in which the construction of new national identities rooted in the pre-1947 anti-colonial discourses shaped by the antagonisms between the Congress and the Muslim League played a central role. These differences would eventually crystallise in the armed rivalry that would lead to four wars, the nuclearisation of South Asia, and with Kashmir as the enduring symbol of the divide. Equally important were the efforts to regulate access to, and the religious shrines of, minority religious communities in the new states which become a barometer of Indo-Pakistan relations. For religious minorities like the Sikhs, whose sacred shrines are shared between India and Pakistan, this has posed some unique dilemmas.

Since the early 1950s, the formal management of evacuee shrines and pilgrim visits by citizens of India and Pakistan to each other's countries are regulated by treaties and protocols. The Liaquat-Nehru Pact (1950), agreed after of exodus of Hindus from East Pakistan in 1950, was a bilateral treaty which offered protection to minority rights and gave the right to refugees to return and dispose of their property (India Treaty Series 1950). Although the text of the treaty refers primarily to East Pakistan, for the Shiromani Gurdwara Prabandhak Committee (SGPC) it justifies its claims to manage gurdwaras in Pakistan (Rana 2014). This understanding appears to have been compromised by a secret agreement between India's Minister for Home Affairs, Govind Ballabh Pant and Pakistan's Prime Minister Sikandar Mirza in 1955, to treat Sikh shrines and property attached to them, including Nankana Sahib, as 'evacuee property' to be disposed of as ordinary holdings (Lal 2014) . 
Following the creation of Bangladesh, the Shimla Agreement (1972) committed India and Pakistan to open trade and communications and promote "travel facilities for the nationals of the other country' (Ministry of External Affairs, n.d.(a)) The agreement was accompanied by the Protocol on Visits to Religious Shrines (1974) which approved such visits 'without discrimination to religion or sect' to a designated list of shrines (18), limiting to a maximum of 20 parties per year from each country, though the numbers of each party can vary. The protocol also required that every 'effort should continue to be made to ensure that places of religious worship mentioned in the agreed list are properly maintained and their sanctity preserved' (Ministry of External Affairs, n.d. (b)). For Sikh pilgrims in India, such visits are limited to the birth anniversary of Guru Nanak and vaisakhi, the martyrdom of Guru Arjan and the birth anniversary of Maharaj Ranjit Singh, though the range and number of visits seems to have expanded greatly since (Sikhsangat 2011). In 1999, partially in response to the concerns raised by the Sikh diaspora about the conditions of Sikh gurdwaras in Pakistan, the government of Pakistan formed the Pakistan Sikh Gurdwara Prabandhak Committee (PSGPK) to oversee the work Evacuee Trust Property Board which is formally entrusted with managing Sikh shrines (Khalid 2018, 18); and despite heightened hostility between India and Pakistan after 9/11 and the terrorist attack on the India parliament (2001), which led to a general mobilisation between the two countries, in the ensuing détente several initiatives were taken to improve East/West Punjab dialogue, including preliminary efforts to open up the Kartarpur corridor and a bus service from Amritsar to Nankana Sahib (2006) (Talbot 2010). But these symbolic measures have struggled to overcome bureaucratic, security and diplomatic hurdles. The bus service, for instance, was heavily curtailed following the terrorist attacks in Mumbai (2008); it has struggled in recent years to secure enough passengers to make the journey economic viable (Bassi 2017). In the heightened state of tension between India and Pakistan following the turmoil in Kashmir and the 'surgical strike' across the Line 
of Control (September 2016), pilgrims have once again been limited to 'special trains' as the preferred mode of transportation.

However, these regimes of control have been increasingly subverted by the emergence of a Sikh diaspora (Tatla 1999). In the mid-1970s, Ganga Singh Dhillon, a Washington-based businessman, with extensive networks in the US political establishment, created the Nankana Sahib Foundation (1974) for the preservation and maintenance of Sikh sacred shrines in Pakistan. The objective was to establish an international organisation run by Sikhs to manage these institutions. Dhillon formed a close friendship with Pakistan's military leader President Zia-ul-Haq, a refugee from East Punjab, who recognised the importance of providing free access to, and freedom of worship, at these shrines in shaping Sikh sentiment in India and the diaspora (Badhwar 1981). Following the entry of the Indian army into the Golden Temple in June 1984, the Government of India in its White Paper attributed the militant violence in Punjab to the material and political support provided by Pakistan (Government of India, 1984); and in the decade long insurgency that ensued thereafter, Pakistan was accused not only of supporting the militants but also of manipulating Sikh religious sentiment in fostering Sikh religious separatism. Such encouragement, according to Talbot $(2010,70.73)$, coincided with the latter's strategic objective of 'opening another "front" in its covert conflict with India'.

After 1984 most of the leading Sikh militant groups were based in Pakistan. They were supported discretely by the Pakistan intelligence agencies but kept at arm's length from the major Sikh shrines that were the subject of agreement between India and Pakistan. Nonetheless, as the human rights violations and counter-insurgency efforts of the Indian state intensified, especially from the mid-1980s to the 1990s (Pettigrew 1995), annual religious 
events became occasions for the mobilisation by the Sikh diaspora. Indian diplomats regularly complained to Pakistani officials that scared sites such as Nankana Sahib were being used for the promotion of Sikh separatist activities and anti-Indian propaganda (The Times of India, July 3, 1997).

Since the 1990s, Sikh shrines in Pakistan have become sites of major organised pilgrim tours. This change is in part reflective of the broader trends in global tourism in which sacred spaces have become the destinations of mass pilgrimage in the age of globalisation and cheap tourism (Timothy and Olson 2006). It is also the result of sustained private initiatives by local sants (religious leaders) who command sizable congregations, and have started the process of leading the faithful to rediscover a lost heritage (Tatla 1992) Gurdwaras, community groups and families in the diaspora regularly organise such tours to leading shrines on key dates in the Sikh calendar. These tours are publicly advertise in the Punjabi media, and travel agencies based in Pakistan catering for the growing Sikh pilgrim market have proliferated, offering bespoke tours to more general accommodation of large parties. ${ }^{\text {iii }}$ This market is likely to expand rapidly as Pakistan has further liberalised travel from the Sikh diaspora with facilities for visa on arrival, by actively promoting its cultural 'soft power', and encouraging new interest in Sikh cultural and religious inheritance in Pakistan reflected in such publications as Singh's Lost Heritage: The Sikh Legacy in Pakistan (2016) and Khalid's Walking with Nanak (2018). The prospects of large-scale pilgrimage to Pakistan, which now is being portrayed as the 'religious home' of the Sikhs, is likely to be welcomed by the diaspora, and Sikhs in East Punjab. It also however has the potential to raise some unsettling questions about the current regimes for access to, and management of, Sikh religious shrines and create new imaginaries of Sikh 'holy land' and 'home land'. 


\section{The Kartarpur Corridor}

It is against this broad historical background that current decision of the Pakistan government, and India's positive response to it, needs to be understood. Officially, the initiative 'is in line with Islamic principles that advocate respect for all religions and Pakistan's policy of promoting interfaith harmony and religious tolerance' (Yousaf 2019).

Realistically, however it is driven by the need for a rapprochement with India following the spike in terrorist incidents in Jammu and Kashmir since 2014, and Pakistan's increasing domestic financial difficulties. Similarly, India's begrudging engagement with the process, has been influenced largely by the potential impact on Sikh voters in the forthcoming parliamentary elections in Punjab (Sevea 2018). But these short-term considerations apart, the strategic imperatives for both states remain the same: to manage, regulate and control access to Sikh scared shrines the existence of which radically disrupts the new sacred geographies of post-1947 Indian and Pakistani nationalisms.

Unconventionally, the current move to open the Kartarpur corridor was instigated by the maverick ex-cricketer turned politician, Navtej Singh Sidhu, during his visit to Prime Minister Imran Khan's inauguration on 18 August 2018. At the ceremony, Sidhu was assured by the Pakistan Army Chief, General Qamar Javed Bajwa that serious steps would be taken to open a corridor for the Kartarpur Sahib Gurdwara in Pakistan on the occasion of $550^{\text {th }}$ birth anniversary of Guru Nanak's birth. Sidhu, who was universally condemned for his visit in the Indian press for fraternising with the enemy, and hugging the Pakistan army chief while Indian soldiers were being killed in Kashmir, remained unrepentant, arguing against his party (Indian Express, 19 August, 2018). Weary that the initiative was passing to Pakistan, on 26 November, 2018, amid confusion and chaos, Vice President Venkaiah Naidu and Captain 
Amrinder Singh, Chief Minister of Punjab, laid the foundation stone of the Dera Baba NanakKartarpur Shaib corridor (Dhaliwal 2018a). The sanctity of the occasion however was marred by the political rivalry between the BJP and the Congress as the former's representative tried to appropriate the event against the all too public protests of the latter (Dhaliwal 2018b)

In Pakistan, the ground-breaking ceremony at Kartarpur was attended by Imran Khan, the Pakistan Army Chief, dignitaries, and politicians and officials invited from India. In his speech Khan observed that the 'happiness he saw on the faces of the Sikh pilgrims was like Muslims feel when they reach near Makkah or Medina'. While regretting the state of the current affairs between India and Pakistan, he called for a 'civilised relationship' between the two states, pleaded for a resolution of the 'Kashmir problem', and strong economic ties between the subcontinental neighbours, (The News, 28 November, 2018). Interestingly in moving this initiative Khan was adamant that his 'government, his party, all political parties, the military and all Pakistani institutions were on the same page' (Sevea, 4). In responding to Khan's speech, Harsimrat Kaur Badal, a senior stalwart of the SAD, and a Union Cabinet Minister, declared that 'This is a historic day for our [Sikh] nation. Desires of millions of Sikhs around the world have been fulfilled today.' She concluded by labelling the initiative as 'peace corridor' which could become the basis of a 'new start between India and Pakistan' (Ibid., emphasis added).

Since the ceremonies the process of creating the corridor has become ensnared in all too familiar hurdles. In India, the Chief Minister in Punjab has vented his frustration at the reluctance of the Centre to sanction the necessary funds for development to start the construction of the infrastructure for the corridor. Vocal voices in the press, too, have raised security concerns about the development, with some sections openly hostile, citing the legacy of Sikh militancy and the on-going insurgency in Jammu and Kashmir (Davar 2019). In Pakistan, no formal opposition has 
been expressed against the initiative, but the process of building the corridor appears to be reinventing the old security structures which militate against the free movement of pilgrims. In a 59-page document submitted to the Indian officials at the end of December 2018, Pakistan's officials made 14 recommendations which included: the construction of facilitation and security centres on both sides of the corridor; group visits by pilgrims with a minimum of 15 persons per groups; a maximum of 500 visitors a day; a special permit to be issued to visitors by the Government of Pakistan; the list of visitors to be communicated to Pakistan three days in advance of any visit; all visitors to carry an Indian passport; and all visitors would be required to obtain a security clearance certificate from Indian authorities (The Tribune, 30 December, 2018). Surprisingly, no mention has been made of reciprocal travel arrangements on the Indian side if Sikhs - and, indeed non-Sikhs based in Pakistan - wish to visit Dera Baba Nanak.

For Capt. Amrinder Singh these impediments run counter to the promise of khula darshan (open access) of Darbar Kartarpur Sahib for all. The idea of 'hassle free travel', which is central to connecting the two shrines, according to him, is being gradually undermined at the behest of BJP's communally-minded politicians like Vijay Sampla, the Minister for State and Social Justice, who he alleged is actively aiming to 'scuttle [the] Sikh community's Kartarpur dream' by insisting that a passport and a visa be mandatory requirements for pilgrims. Sampla's outlook, Capt.Amrinder Singh insisted, 'was reflective of the BJP's anti-minority attitude and the Modi government's continued attempts to side-line the country's minorities to further its politically motivated agenda' (Rozana Spokesman, 17 January, 2019). Instead of the central governments coordinating and managing these processes, many of the practical issues could be readily resolved by better coordination between the two Punjab authorities. He has also warned the central government against unnecessary procrastination and delay because such action 'would cause untold 
disappointment to the Sikh community based in India as [well] as all over the world' (Business Standard, 17 January, 2019).

Capt. Amrinder Singh's concerns, of course, might well be typical of political rhetoric by a seasoned politician because the two countries are at the beginning of a process of negotiation and bargaining in constructing permanent structures, including a walkway bridge over the Ravi. It is inevitable therefore that there are likely to strong disagreements that might be further compounded by the tight time-frame agreed by both sides to open the corridor by November 2019. But, perhaps more importantly, overshadowing the initiative, as previous episodes of India-Pakistan détente have illustrated, is the spectre of unexpected political developments - the impending national elections in India, a sudden changes in the polity in Pakistan, and terrorist incidents in India, such as the Palwama attack (February 2019) which has led to the recent confrontation between the two countries - that might derail the project. The promise of Kartarpur co-exists with the ever-present realities of the Indo-Pakistan relationship.

Yet these realities belie how the Karartpur corridor process is being managed by the two states to assert political sovereignty over access to Sikh sacred spaces. Ostensibly, these claims of sovereignty are evident in the requirement of visas, passports and security clearance - against the desire of the regional Sikh population for open travel. Lurking behind these formalities are the traditional fears of unintended consequences for the 1947 settlement if access to Sikh shrines, and indeed, travel across the borderline, becomes unregulated, or can no longer be managed by India and Pakistan. While the parallels with Eastern European states just before the collapse of the Berlin Wall are probably unwarranted, the post-1947 political elites in India and Pakistan have sedulously avoided unfettered movement across the 
border line, either in Punjab or Kashmir. The promise of the South Asian Association for Regional Cooperation (SAARC) to create borderless travel in South Asia has remained largely unfulfilled. Thus, whatever the local arrangements are made to make access less burdensome, national governments will maintain the regimes of control of access that they have so heavily invested in since independence.

Moreover, the discourses used by the leaders of India and Pakistan in launching the initiative reinforce the conventional narratives of nationhood that led to 1947. For Pakistan, the measure is entirely consistent with its self-image as an 'Islamic republic' promoting interreligious harmony and protecting the rights of religious minorities. An official press note also added, somewhat facetiously, probably as an afterthought, that the proposal was in line 'line with Quadi’s (Jinnah's) vision of a peaceful neighbourhood' (Daily Messenger, 22 January, 2019). But as Talbot $(2010,73)$ has pointed out, the Pakistan state is much more inclined to deal with religious categories than ethnic ones because 'the emphasis on access to sacred spaces, rather than on, for example, improving cultural exchange', means that 'Punjabi ethnonationalists [can] continue to be marginalised in the region that forms the core component of the Pakistan state'. Designating Sikh issues as religious one, and one essentially of access to sacred spaces controlled and managed by the Pakistan state, denudes them of their shared political and cultural importance that contradicts the official narrative of the two-nation theory.

Likewise, the Indian state's understanding of the initiative, with its emphasis on Sikhs as individual citizens who practice religion within the private realm - not as a corporate religio-political community - is entirely consistent with the post-1947 construction of religious minorities as communities of culture, without any claims on public space or 
institutions (Kim 2019). But while minority religious communities like the Christians, Muslims and Sikhs have been politically disarmed, the Congress and the Bhartiya Janata Party (BJP) have actively promoted Hinduism as form of secularised majoritarianism, an ideal type of civic religion (Embree 1990). This structural imbalance in the nature of Indian state secularism has created a context in which political representatives of religious minorities have to frame their demands in the idiom of the dominant discourses of majoritarianism. Hence the objections of Capt. Amrinder Singh, a Congress politician, to Pakistan's initial proposal to limit access to Sikhs only. Hence, too, his rather curious explanation why such an exclusive interpretation of Sikh identity by the Pakistan state would be deemed offensive to many Hindus - not necessarily other religions - who have historically viewed Sikhism within the broader Hindu tradition (National Herald, 23 January, 2019). While Arminder Singh's views reflect the assimilations strands of modern Hindu nationalism, its more overt manifestations are evident in Sampla's efforts to 'scuttle' the initiative by creating unnecessary hurdles and BJP orchestrated attempts to control leading Sikh shrines. This new development has led to open conflict between the BJP and the SAD (The Tribune, January $31,2109)$.

The Kartarpur corridor has also begun to reveal the underlying anxieties of governments in India and Pakistan in how to manage the 'Sikh question', a question which was the main cause of the division of the province in 1947 and its bloody aftermath. For governments in Pakistan, Sikhs and Sikh issues remain an instrumental object. The narrative of Sikh community as an 'asset' is so deeply embedded in the official historiography of Pakistan which, incidentally, regularly portrays the Sikh leadership as beguiled led by the Congress into demanding the division of the province in 1947 (Talbot 2010; Mirza, Hasnat, and Mahmood 1985; Hussain 1984), that it is difficult to envisage how it can be readily 
revised to offer a more open, welcoming vision of nationhood in which minorities are tolerated and celebrated. The corridor might be the beginnings of such a process; history cautions us against such an optimistic reading, however.

Similar anxieties are evident in how governments in India have framed policies on Sikhs and Sikh issues. The rhetoric that the corridor could 'become a symbol of love and peace between the two countries' (Hindustantimes, 26 November, 2018)), co-exists uneasily with profound misgivings about militant Sikh terrorism, Pakistan's design, and the loyalty of a community that is traditionally viewed as sentinels on the border (Pandy 2019). The literature on the counterinsurgency in Punjab between 1984 and 1993, for example, is dominated by discourses of how Sikhs were prone to emotional manipulation by Pakistan, denying the community or its individuals any sense of agency over its own affairs (Dhillon 2006). Even after1947, unsubtle attempts were made by the Congress to communalise the Punjabi Suba movement, conceding the linguistic reorganisation of the province only as a matter of 'principle' following the Indo-Pakistan war of 1965. As a non-Hindu majority, peripheral border state, ethnic conflict in Punjab has been by managed by 'hegemonic control'; and when this has broken down, as was the case after 1984, it has been replaced by 'violent control' (Singh 2000, 47). More recently, with the rise of Hindu nationalism as the governing ideology of the state, efforts have been made to assimilate the Sikh tradition within the pantheon of Hinduism. Whereas the BJP and its Sangh parivar (family of organisations of the Hindu Right) have embarked on a strategy of culturally and politically excluding Christian and Muslim minorities, Indic religious minorities, such as Buddhist, Jains and Sikhs, have been subject to integrationist and assimilative pressures (Kim 2017). Since the formation of BJP-led National Democratic Alliance government in 2014, institutions of religious minorities, including educational institutions, have been subject to strict regulatory 
controls and infiltration by Hindutva ideologues who have systematically undermined their independence and autonomy. And in the making of what Baru (2013) has called the 'Second Indian republic', in which Hindu nationalism is firmly displacing Nehruvian secularism as the governing ideology, the religious terms of trade between Hinduism and Sikhism are now firmly in the former's favour (Singh and Shani 2020). Whether in the medium term Sikh religious or political autonomy will survive, or might become part of new imaginings, that also includes West Punjab, remains to be seen.

\section{Conclusion}

In the comparative analysis of control of sacred spaces, the Sikh case-study offer an unusual example that defies clear classification. It is not a struggle for 'indivisibility' against another faith tradition or sect for sole ownership of sacred spaces. Nor does it resemble the case of settler and colonial societies where sacred spaces were reassigned new functions by postcolonial states or indigenous societies. Nor, still, does it have parallels in the consequences which followed the creation of modern authoritarian political systems or the establishment of Communist regimes post-1945, either in Eastern Europe or developing states in the South, where religious practices, especially of minorities, were proscribed. Rather, for Sikhs, including those in the diaspora, access to leading religious shrines of the community has been denied to them since 1947 in what has traditionally been viewed as their 'homeland' and 'holy land'. Because this 'homeland' was an integral part of the Congress and Muslim League's drive for nation statehood, both before and after 1947, the division of the Punjab, with the simultaneous division of the Sikh community, and its sacred spaces, was deemed as the necessary consequence of India's decolonisation by the three principal parties to the process - the British government, the Congress and the Muslim League. This unspoken 
assumption was made palatable by the device of the Boundary Commission; its consequences were the cataclysmic outcomes of the Commission's award.

The Sikh leaders' opposition to the division of the Punjab was rooted in the community's spiritual, economic and cultural heritage within the province that did not conform to the principle of Muslim and non-Muslim majority areas. At the heart of this opposition was the prospect of inclusion of leading gurdwaras, like Nankana Sahib, in the new state of Pakistan. These sacred spaces had been critical in the development of a modern Sikh identity in which Sikhs had reimagined themselves as a religiously and politically sovereign, with the SAD and the SGPC emerging as the institutional elements of the 'Sikh political system' (Singh and Shani, ch.2; Fox 1985; Oberoi 1994). But because this idea of religious and sovereignty offered a radically different vision of post-colonial Punjab, and indeed India, than contemplated by either the Congress or the Muslim League, it was not seriously entertained by the British who viewed the Sikhs as a 'nuisance'. ${ }^{\text {iv }}$

Since 1947, the partition has become the national foundational myth of India and Pakistan (Talbot and Singh, 130-1). In the case of the former, it has led to the creation of a highly centralised secular state in which religious minorities have been de-politicised; in the latter, the failure of democratisation has produced long period of military rule with the Islamciation of the state. Ironically, despite these prima facie differences, both states have followed remarkably similar policies in managing Sikh issues: whereas in Pakistan the creation of the international border has enabled the state to control and regulate access of Sikhs to sacred spaces in West Punjab, in India, Sikhs' religious and political freedoms have been heavily circumscribed, culminating in the army's entry into the Golden Temple. Not unnaturally, therefore, the regimes for managing Sikh sacred spaces in both East and West 
Punjab are characterised by a high degree of political sensitivities in efforts to control, define and regulate access to, and functions of, Sikh scared spaces.

The opening of the Kartarpur corridor offers a beacon of hope in otherwise a conflicttorn Indo-Pakistan relationship. But this initiative needs to be situated in its appropriate historical context: namely, that neither state's approach marks a new departure from the logic of partition as a necessary evil. For Sikhs, unfettered access to the community's sacred and cultural spaces in their 'homeland' and 'holy land' is unlikely to overcome the considerable barriers created by Indian and Pakistani nation-statehood anytime soon. Thus, the Kartarpur corridor might well become a 'bridge of peace' between India and Pakistan; it is also however likely to remain 'a bridge too far' for the Sikh community because that which is near and dear will continue to remain so elusive.

\section{Acknowledgements}

I should also like to acknowledge the helpful comments of Prof. Arvind-pal S. Mandair, Prof Ian Talbot and Dr Tom Lyne.

\section{Funding details}

This article is the outcome of a Leverhulme Trust Research Fellowship number RF-2018064/6 on "A World Turned Upside Down: Sikhs and the Partition of India." The support of the Trust is gratefully acknowledged.

\section{Disclosure statement}

No potential conflicts of interest were reported by the author.

\section{References}

Ahmed, Ishtiaq, 2000. "The Partition of Punjab: Arguments put forth before the Punjab Boundary Commission." In Region and Partition: Bengal, Punjab and the Partition of the Subcontinent, edited by Ian Talbot and Gurharpal Singh, 116-167. Karachi: Oxford University Press. 
Badhwar, Inderjit.1981. "I don't need Zia or the CIA to tell me what to do: Ganga Singh Dhillon.” India Today, 25 October. Accessed 27 January 2019.

https://www.indiatoday.in/magazine/international/story/19811130-i-am-an-agent-of-gurunanak-ganga-singh-dhillon-773466-2013-10-25

Bar, Sanjaya.2014. The Accidental Prime Minister: The Making and Unmaking of Manmohan Singh. New Delhi: Penguin Books.

Bassi, Assem. 2017. "India and Pakistan buses struggle to get passengers." Hindustantimes, 20 May. Accessed 27 January 2019. https://www.hindustantimes.com/punjab/indo-pakbuses-struggle-to-get-passengers/story-BWKpYPMhdvIkNoJJOu2pYK.html

Brass, Paul R.2003. "The Partition of India as Retributive Genocide in the Punjab, 1946-7: Means, Methods, and Purpose." Journal of Genocide Research 5(1): 71-101.

Business Standard.2019. “Captain Amarinder accuses Sampla of complicating travel process to Kartarpur Sahib.” 17 January. Accessed 18 January 2019., https://www.businessstandard.com/article/news-ani/captain-amarinder-accuses-sampla-of-complicating-travelprocess-to-kartarpur-sahib-119011700831_1.html).

Casanova, Jose.1994. Public Religions in the Modern World. Chicago: University of Chicago Press.

Daily Messenger. 2019. "Pakistan invites Indian delegation to finalise agreement.", 22 January. Accessed 30 January 2019. https://www.pressreader.com/).

Davar, Kamal.2019. "Mischief and myopia are Imran's policy guidelines.” The Tribune, 13 February 2019. Accessed 13 February 2019.

https://www.tribuneindia.com/news/comment/mischief-and-myopia-are-imran-s-policyguidelines/728022.html

Dhaliwal, Ravi.2018a. "Chaos, confusion on eve of Kartarpur corridor stone-laying ceremony.” The Tribune, 25 November 2018. Accessed 30 December 2018.

https://www.tribuneindia.com/news/punjab/chaos-confusion-at-venue-on-eve-of-kartarpurcorridor-stone-laying-ceremony/688745.html).

Dhaliwal, Ravi.2018b. "Showdown at Kartarpur." The Tribune, 27 November 2018, Accessed 30 December 2019. https://www.tribuneindia.com/news/punjab/chaos-confusionat-venue-on-eve-of-kartarpur-corridor-stone-laying-ceremony/688745.html).

Dhillon, Kirpal. 2006. Identity and Survival: Sikh Militancy in India 1978-1993. New Delhi: Penguin.

Embree, Ansile, T. 1990. Utopias in Conflict: Religion and Nationalism in Modern India. Berkeley: University of California Press.

Fox, Richard G.1985. Lions of the Punjab: Culture in the Making. Berkeley: University of California Press. 
Government of India.1984. White Paper on the Punjab Agitation. Delhi: Government Publications.

Hansard.1947. 14 July, vol.440, column, 74. Accessed $2^{\text {nd }}$ February 2019. https://hansard.parliament.uk/Commons/1947-07-14/debates/9b529b5a-0410-4666-8d0a715a12232dad/Clause3\%E2\%80\%94(BengalAndAssam)?highlight=henderson\#contributionc811385d-d026-4a11-a3cb-6da28705b3cb

Hassner, Ron E. 2003. "“To Have and to Hold': Conflict Over Sacred Spaces and the Problem of Indivisibility.” Security Studies 12 (4):1-33.

Hindustantimes.2018. "Kartatpur corridor will become symbol of love between both countries.". 26 November. Accessed 28 November 2018.

https://www.hindustantimes.com/india-news/kartarpur-corridor-updates-venkaiah-naidu-tolay-foundation-stone-today/story-nuKDdpv52SXvTR6LTAmfcN.html

Hussain, S.S.1984. Sikhs at Crossroads. Islamabad: Kamran Publishing House.

India Treaty Series. 1950. "Agreement between the Governments of India and Pakistan Regarding Security and Rights of Minorities." Accessed $4^{\text {th }}$ February 2019. http://www.commonlii.org/in/other/treaties/INTSer/1950/9.html

Indian Express.2018 "Imran Khan sworn in ceremony: In attendance, Sidhu under fire from BJP, SAD; Congress defend." 19 August. Accessed 30 October 2018.

https://indianexpress.com/article/india/navjot-singh-sidhu-pakistan-imran-khan-oath-akalidal-congress-bjp-qamar-javed-bajwa-army-5313888/

Khalid, Haroon.2018. Walking with Nanak. (Chennai: Tranquebar Press)

Kim, Heewon.2017. "Understanding Modi and Minorities: The BJP-led Government in India and Religious Minorities.” India Review 16(4):357-376.

Kim, Heewon.2019. The Struggle for Equality: India's Muslims and Rethinking the UPA Experience. New Delhi: Cambridge University Press.

Lal, Harbans. 2014. "He served the Sikh nation with passion and dedication: Ganga Singh Dhillon." SikhNet, 28 September 2014. Accessed 4 February 2019.

https://www.sikhnet.com/news/he-served-sikh-nation-passion-dedication-ganga-singh-dhillon

Mandair, Arvind-pal.2015. "Sikhs, Sovereignty and Modern Government." In Religion as a Category of Governance and Sovereignty, edited by Trevor Stack, Naomi R. Goldenberg and Timothy Fitzgerald, 115-132. Leiden: Brill.

Mansergh, Nicholas and Penderal Moon, editors.1980. The Transfer of Power, 1942-7, Vol. $I X$. London: Her Majesty's Stationary Office.

Mansergh, Nicholas and Penderal Moon, editors. 1981. The Transfer of Power, 1942-7, Vol.X. London: Her Majesty's Stationery Office. 
Mansergh, Nicholas and Penderal Moon, editors.1982. \The Transfer of Power, 1942-7, Vol.XI. London: Her Majesty’s Stationery Office.

Mansergh, Nicholas and Penderal Moon, editors. 1983. The Transfer pf Power, 1942-7, Vol. XII. London: Her Majesty's Stationery Office.

Ministry of External Affairs. (n.d. (a)). "Simla Agreement July 2, 1972.” Accessed 10 February 2019. https://mea.gov.in/in-focus

article.htm?19005/Simla+Agreement+July+2+1972

Ministry of External Affairs. (n.d. (b)). "Protocol on Visits to Religious Shrines, September 14, 1974.” Accessed 12 January 2019. https://mea.gov.in/bilateraldocuments.htm?dtl/6199/Protocol+on+visits+to+Religious+Shrines

Mirza, Safraz Hussain, Syed Farooq Hasnat, and Sohil Mahmood. 1985. The Sikh Question: From constitutional demands to armed conflict. Lahore: Centre for South Asian Studies.

Moore, R.J.1983. Escape From Empire: The Attlee Government and the India Problem. Oxford: Clarendon Press.

Mountbatten, Lord Louis.1947. "Viceroy's Personal Report No. 3, 17" April. L/PO/6/123, ff24-50, India Office Record.

National Herald. 2019. "Punjab CM Amrinder Singh protests against Pakistan move to restrict Kartarpur travel to Sikhs only." 23 January 2019. Accessed 30 January 2019. https://www.nationalheraldindia.com/national/punjab-cm-amarinder-singh-protests-againstpakistans-move-to-restrict-kartarpur-travel-to-only-sikhs

Oberoi, Harjot.1994. The Construction of Religious Boundaries: Culture, Identity and Diversity in the Sikh Tradition. New Delhi: Oxford University Press.

Pandy, Abhinav.2019. "India fears revival of Sikh militancy." Fair Observer, 29 January. Accessed 30 January 2019.

https://www.fairobserver.com/region/central_south_asia/khalistan-movement-punjab-sikhmilitancy-pakistan-news-14312/

Pettigrew, Joyce, J.M.1995. The Sikhs of the Punjab: Unheard Voices of State and Guerrilla Violence. London: Zed Press.

Rana, Yudhvir.2014. "Calendar. Makkar Returns without any assurances from PSGPC.” The Times of India, 23 May. Accessed 12 January 2019.

https://timesofindia.indiatimes.com/india/Calendar-Makkar-returns-without-any-assurancefrom-PSGPC/articleshow/35490430.cms

Rozana Spokesman. 2019. "Capt lashes out at Sampla for trying to scuttle Sikh Community Kartarpur Sahib Dream.” 17 January 2019. Accessed 20 January 2019. https://www.rozanaspokesman.com/news/punjab/170119/capt-lashes-out-at-sampla-fortrying-to-scuttle-sikh-community-kartarp.html). 
Sevea, Iqbal Singh. 2018. "The Kartarpur Corridor: Symbolism, Politics and Impact on IndiaPakistan Relations." Institutes of South Asian Studies Insights. No.525, 11 December, 1-15. https://www.isas.nus.edu.sg/wp-content/uploads/2018/12/ISAS-Insights-No.-525-TheKartarpur-Corridor.pdf

Sikhsangat.2011. "Kartarpur corridor: Ball in India's courts, says Pak." The Tribune, 30 November. 30 November 2011. Accessed 22 February 2019.https://www.sikhsangat.com/index.php?/topic/64242-kartarpur-sahib-corridor-ball-inindia\%E2\%80\%99s-court-says-pak

Singh, Amardeep. 2016. Lost Heritage. The Sikh Legacy in Pakistan. New Delhi: Himalayan Books.

Singh, Gurdit and Carol C.Fair.2000. "The Partition of Punjab: Its Impact upon Sikh Sacred and Cultural Space." In Region and Partition: Bengal, Punjab and the Partition of the Subcontinent, edited Ian Talbot and Gurharpal Singh, 253-268. Karachi; Oxford University Press.

Singh, Gurharpal.2000. Ethnic Conflict in India: A Case-Study of Punjab. London: Macmillan Press.

Singh, Gurharpal. 2013. "Sikhs and Partition Violence: A Re-evaluation." In The Independence of India and Pakistan: New Approaches and Reflections, edited by Ian Talbot, 120-130. Karachi: Oxford University Press.

Singh, Gurharpal and Giorgio Shani.2020. Sikh Nationalism (forthcoming).

Singh, Kirpal, edited.1991. Selected Documents on Partition of Punjab-1947 India and Pakistan. Delhi: National Book Shop.

Talbot, Ian, and Gurharpal Singh.2008. The Partition of India. Cambridge: Cambridge University Press.

Talbot, Ian.2010. "Pakistan and Sikh Nationalism: State Policy and Private Perceptions." Sikh Formations 6(1):63-76.

Tatla, 1992. "Nurturing the faithful: The role of Sants among British Sikhs." Religion 22(4):349-374.

Tatla, Darshan Singh.1999. The Sikh Diaspora: The search for statehood. Seattle; University of Washington Press.

The News.2018. "PM Imran Khan performs ground-breaking of Kartarpur corridor." 28 November. Accessed 29 December 2019. https://www.thenews.com.pk/latest/399393-liveupdates-kartarpur-corridor-inauguration).

The Times of India.1997. "Pakistan allows anti-India propaganda violating deal." 3 July. 
The Tribune.2018. "Pak for visa-free Kartarpur corridor." 30 December. Accessed 2 January 2019.https://www.tribuneindia.com/news/punjab/pak-for-visa-free-kartarpur-corridortravel/706077.html8).

The Tribune. 2019. "Don't meddle in gurdwara affairs, SAD warns BJP." 31 January. Accessed 4 February 2019. https://www.tribuneindia.com/news/punjab/don-t-meddle-ingurdwara-affairs-sad-warns-bjp/721208.html

Timothy, Dallen, J. and Daniel M. Olsen, editors.2006. Tourism, Religion and Spiritual Journeys. Abingdon, Oxon: Routledge.

Yousaf, Kamran.2019. "Indian team invited to finalise Kartarpur deal." The Express Tribune, 21 January. Accessed 23 January 2019. https://tribune.com.pk/story/1893442/1-kartarpurcorridor-pakistan-invites-indian-delegation-finalise-agreement/

Zamindar, Vazira Fazila-Yacoobali.2007. The Long Partition and the Making of Modern South Asia: Refugees, Boundaries, Histories. Columbia: Columbia University Press.

\section{Notes}

\footnotetext{
'Sacred spaces, according to Hassner $(2003,5)$, are characterised by three functions: 'they are places of communication with divinity through prayer, movement or visual contact with images of the divine; they are places of divine presence, often promising healing, success or salvation, and they provide meaning to the faithful for metaphorically reflecting the underlying order of the world'. To be recognised as such these places need to have centrality and exclusivity for the faithful. The major Sikh gurdwaras in West Punjab associated with the gurus, as we shall see, fulfil the definition of sacred spaces and the criterions of centrality and exclusivity. For clarity we use the terms sacred spaces, shrines and gurdwaras as they pertain to the Sikh community's case interchangeably, though were recognise the conceptual and institutional differences among them.

ii The terms of reference of the Boundary Commission were agreed by the leaders of the Congress, Muslim League and the Sikhs. Initially, Mountbatten asked each to send him a draft. Nehru wrote to reject the involvement of the UNO, agreed to the principle of continuous majority Muslim and non-Muslim areas, and as a concession to the Sikhs, stipulated that it should 'take into account other factors' (Mansergh and Moon 1982, 239). At the Viceroy's Executive Council meeting held on $13^{\text {th }}$ June 1947 to confirm the terms of reference, Baldev Singh did not speak (Ibid., 382).

iii A simple search on Google of 'Sikh pilgrimage tours to Pakistan' generates a large number of sites based in Pakistan. Sikh Tourism, for example, claims 'Today's Pakistan is the cradle of the Sikh religion. We proudly claim that Guru Nanak Dev Ji was born in this part of the subcontinent, spent most of his time here.... and have more than ninety per cent of the Sikh shrines in Pakistan.' See http://www.sikhtourism.com.pk/index.php. Accessed 20 February 2019.

${ }^{i v}$ For a discussion of the concept of sovereignty within the Sikh tradition, see Mandair (2015).
} 